\title{
25 Research Soure \\ First Record of A New Microsporidium Pathogenic to the Eucalyptus Snout Beetle in Brazil
}

Carolina Jordan ( $\square$ carolina.jordan@unesp.br)

School of Agricultural Sciences, São Paulo State University (UNESP), Campus of Botucatu

Vanessa Carvalho

School of Agricultural Sciences, São Paulo State University (UNESP), Campus of Botucatu

Gabriel Mascarin

Laboratory of Environmental Microbiology, Brazilian Agricultural Research Corporation, Embrapa

Environment

Leiliane Oliveira

Botucatu Medical School, Dept. Internal Medicine, Sao Paulo State University (UNESP), Campus of

Botucatu

Christopher Dunlap

USDA, Agricultural Research Service, National Center for Agricultural Utilization Research, Crop

Bioprotection Research Unit

Carlos Wilcken

School of Agricultural Sciences, São Paulo State University (UNESP), Campus of Botucatu

\section{Research Article}

Keywords: Invasive pest, biological control, Gonipterus platensis, entomopathogens, eucalyptus beetle, Vairimorpha.

Posted Date: January 15th, 2021

DOl: https://doi.org/10.21203/rs.3.rs-144248/v1

License: (c) (i) This work is licensed under a Creative Commons Attribution 4.0 International License. Read Full License 


\section{Abstract}

Microsporidia are naturally occurring fungal-related parasites that can infect nearly all animal hosts, but their biocontrol potential of insect pests is routinely overlooked in agriculture and forestry. This research brings the first report describing the natural occurrence of a microsporidium causing disease in fieldcollected populations of the invasive eucalyptus snout beetle, Gonipterus platensis (Coleoptera: Curculionidae), a major destructive pest of eucalyptus plantations in Brazil. Adult beetles were collected during field surveys in commercial eucalyptus plantations in southern Brazil to be examined and dissected with typical symptoms to verify presence of microsporidian spores in haemolymph. From 14 plantations in different sites, the natural infection occurrence in these populations ranged from 0 to $65 \%$, while a lab colony exhibited an infection incidence of $70 \%$. Spore density in haemolymph of symptomatic insects averaged $2.1( \pm 0.4) \times 10^{7}$ spores $/ \mathrm{mL}$. Symptoms in infected adults were identified by abnormal abdomen with malformation of the second pair of wings, impairing their flight activity. Electron transmission microscopy of the pathogen showed morphological features similar to species belonging to the genus Nosema or Vairimorpha. Phylogenetic analysis of the full-length small subunit ribosomal RNA gene suggests this pathogen's placement in the genus Vairimorpha, but with a sequence identity of 94\% with the nearest neighbours. The low level of sequence identity suggests this pathogen may represent a novel taxon in the genus and further requires whole genome sequencing for definitive taxonomic resolution. These findings provide insights on the natural occurrence of this novel pathogen for potential use in biocontrol of this invasive pest in Eucalyptus plantations in Brazil, and prompts the design of conservative or augmentative strategies for the establishment of this microsporidium in field populations for sustainable management of eucalyptus snout beetles.

\section{Introduction}

Various environmental, biological and genetic factors can influence performance and fitness during an insect's life cycle. A relevant factor is the occurrence of pathogens such as bacteria, viruses, fungi, and parasites that are responsible for about $80 \%$ of the diseases in insect populations ${ }^{1}$. Recent research has highlighted several cases of success in insect invasions facilitated by microorganismsc $2,3,4,5,6$, including some microsporidia.

Microsporidia have been reported to cause substantial deleterious effects on host fitness in other host insects. These effects include malformations in infected pupae, increased larval mortality, developmental delay of immatures, reduced fertility and longevity of adults, and increased susceptibility to stress conditions ${ }^{7}$. These stress factors cause biological changes in the host insect and may be associated with the failure of its parasitism ${ }^{1}$. As microsporidian pathogens generally display efficient transmission mechanisms and moderate virulence, these traits may make them more effective agents in establishing enzootics in host population ${ }^{8}$, as evidenced by the use of a microsporidium to control locusts ${ }^{9}$. In this context, microsporidian entomopathogens hold a great potential as long-term biocontrol agents of 
numerous arthropod pests, but their natural incidence and pathogenicity in populations of forest pests have been underexplored ${ }^{10}$.

In the past, microsporidia were considered to be spore-forming protozoa, but in the light of modern taxonomy, this group was relocated to in or near the Fungi kingdom and are now called non-flagellate, single-celled fungi, and obligate intracellular parasites ${ }^{11}$. Several studies suggest a new classification for microsporidia within or near the fungi group, and the majority of entomopathogenic microsporidia belong to the genus Nosema, with more than 150 insect host species described in 12 insect orders, notably Lepidoptera, Hymenoptera, Diptera, Orthoptera and Coleoptera are among them ${ }^{12}$.

Microsporidia generally cause sublethal and chronic deleterious effects in infected hosts and, as a result, are a serious problem in insects that are massively bred in laboratories and bio-factories ${ }^{1,7}$. Spores are generally small and most entomopathogenic microsporidia are approximately 2 to $6 \mu \mathrm{m}$ in length. Spores can have different morphologies, including rounded, oval, or pyriform, and less frequently reniform, long ovals to almost tubular shape and refringent appearance when examined under phase contrast microscopy7.

The Eucalyptus snout beetle (ESB), Gonipterus platensis Marelli 1927, also known as the eucalyptus beetle, is currently the primary coleoptereus pest in commercial eucalyptus forestry in Brazil. ESB is native to Australia, have a high destructive potential as adults and larvae feed mainly on young leaves ${ }^{13}$, and are distributed across the South and Southeast of Brazil ${ }^{14}$. In a study carried out in Portugal, defoliation by $G$. platensis resulted in wood losses of 648 million euros in the last twenty years ${ }^{15}$. This demonstrates the need to better understand the insect in order to have better pest management and avoid losses.

Despite microsporidiosis being reported in a variety of different insect populations, there are no previous studies reporting the presence of this pathogen in populations of G. platensis in the literature. Recently, microsporidiosis symptoms observed in infected adult beetles included typical morphological malformations comprising an abnormal abdomen with the second pair of wings displaced, which impairs flight activity in a laboratory colony. This promptly motivated us to identify the pathogen and determine its prevalence in natural populations. Identifying the pathogen would also allow us to evaluate the potential of the organism to serve as a biological control agent for this pest in forest plantations. The knowledge of the possible microsporidium associated with G. platensis is of great importance to biological control programs attempting to control this pest and to prevent the pathogen from infecting laboratory colonies of this insect.

\section{Results}

\subsection{Morphological characterization and spore density of microsporidium}


Field-collected G. platensis adult beetles were observed with visible symptoms of microsporidiosis disease, as they exhibited notable malformations characterized by spread pair of wings with abnormal and shrivelled abdomen, and the membranous pair of wings completely extended from the elytra (Fig. 1A). In this study, oval spores were identified as resistance structures of intracellular parasites isolated from the body content of $G$. platensis adults. In slides prepared with the beetle's body content, a large amount of spores of the pathogen was easily and clearly observed, which was also used as a quick and easy diagnosis parameter to confirm microsporidiosis in field-collected beetles from different localities, as described later in this study (Fig. 1B). Microscopy is an inexpensive and routine technique for the conformation of microsporidiosis, but it is not an accurate method for species identification since the morphological structures of some pathogens are similar ${ }^{16}$.

Light microscopy revealed that fresh Vairimorpha sp. spore were generally elongated ovoid or oval shapes. Spore dimensions $(n=10)$ averaged $2.07( \pm 0.136) \mu \mathrm{m}$ in length and $1.20( \pm 0.066) \mu \mathrm{m}$ in width, respectively (Fig. 1B). Ultrastructure of microsporidian spores were examined under transmission microscopy and revealed spore wall consisted of an electron-dense exospore. The coiled region of the polar tube comprised 8 turns, and the diplokaryotic nuclei were slightly separated from each other (Fig. 1C). However, this does not discard that this pathogen also forms uninucleate spores as well. All the above-mentioned cellular features corresponded to the basic characteristics found in the genus Vairimorpha. Microsporidian spores from 10 beetles with similar size and weight were collected in Eucalyptus plantation located at São Jerônimo da Serra, SP, Brazil, and presented a sex ratio of 1:1. As result, the averaged of spore load of symptomatic beetles was determined at $2.15( \pm 0.402) \times 10^{7}$ spores per adult with (Fig. 1D).

\subsection{Molecular identification and phylogenetic construction}

Sequencing of the SSU rRNA gene was performed to confirm the identification of the pathogen found infecting populations of $G$. platensis. The PCR results confirmed the isolate was closely related to Microsporidia species, with the highest sequence identity (98\%) to a sequence submitted to Genbank as Microsporidia sp. MB-2008 (GenBank accession no. EU589246). A phylogenetic analysis of the strain and closely related strains of Microsporidia species was conducted (Fig. 2). The closest phylogenetic neighbor of the isolate found in G. platensis was found to be Microsporidia sp. MB-2008, which was isolated from another weevil, Otiothynchus sulcatura (Coleoptera: Curculionidae), followed by Vairimorpha apis, isolated from Apis cerana (Hymenoptera: Apidae). Based on the recent formal redefinition of the genera Nosema and Vairimorpha (Microsporidia: Nosematidae), the strain belongs to the Vairmorpha genus. Based on these findings, the name Vairimorpha curculionidae is proposed, when the species is formally circumscribed in the future.

\subsection{Prevalence of microsporidiosis in different field populations of Gonipterus spp.}

To determine the presence of microsporidium in other populations of the host insect, collections were made at 13 different sampling points distributed in three states as shown in the Fig. 3A. Identification of 
infected adult beetles was based on visual diagnosis of the microsporidiosis symptopms and by checking for spores in hemolymph. Positive results were obtained for microsporidium in most surveyed field sites, including beetles sampled from a mass reared insect colony up to the 2nd generation in Botucatu-SP. There was a significant variation in natural infection caused by microsporidium across different regions or sites of collection in South and Southeast Brazil $\left(\chi^{2}=62.87, \mathrm{df}=13, P<0.0001\right)$. The prevalence of natural infection in these field-collected beetle populations sampled at different locations under field conditions ranged from 0 to $65 \%$, but the highest pathogen incidence was observed in the insect colony maintained at the laboratory corresponding to 70\% infection in adults (Fig. 3B).

Interestingly, it was the first time that we found microsporidium infecting Gonipterus pulverulentus (26.7\% infection), despite the lower frequency of this insect species compared to G. platensis throughout Brazil.

\section{Discussion}

The present work is the first to describe the occurrence of microsporidiosis in an insect colony from the second generation and in field populations of eucalyptus snout beetles collected in commercial Eucalyptus plantations, with the disease being confirmed in two species present in Brazil, G. platensis and G. pulverulentus (Coleoptera: Curculionidae). Microsporidian infections have been reported in other Curculionidae ${ }^{17,18}$ as well as other coleopterans ${ }^{19,20,21,22}$, which demonstrate that this fungal pathogen is more common than previously thought infecting this diverse insect order. Adult beetles collected across the three Brazilian tested positive for the presence of this pathogen. Prevalence of natural infection in these field populations varied from 0 to $65 \%$ and $70 \%$ infection was detected in the lab colony, indicating that this pathogen is spreading with expansion of the pest in Brazil and is established in mass reared lab colonies of ESB.

More than 1400 microsporidian species have been described so far and new species are being discovered each year ${ }^{23,24}$. There are several reports of these microorganisms infecting lepidopterans ${ }^{25}$, hymenopterans ${ }^{26}$ and orthopterans ${ }^{27}$, demonstrating the high genetic plasticity of this group of pathogens. Even more important is the frequent occurrence of microsporidian epizootics in laboratory colonies, in which there is high aggregation and population density of insects facilitating pathogen spread and new infections ${ }^{28}$.

Microsporidiosis is considered an important problem in the life cycle of insects ${ }^{29}$ because of the reduction in pupal size, number and viability, along with a longer duration of the pupal stage ${ }^{30}$. We also described conspicuous morphological abnormalities in infected G. platensis and G. pulverulentus beetles, and these symptoms are good indicators of microsporidiosis diagnostic alongside the presence of spores in the haemocoel. We also observed that adult beetles showcasing wing deformities were unable to fly and had shorter life expectancy relative to noninfected individuals (data not shown).

Spore numbers in G. platensis adult beetles reached an average concentration of $2.15( \pm 0.40) \times 10^{7}$ spores in symptomatic insects. This is similar to other microsporidia infections, Nosema cerane in honey 
bees yielded $1.15 \times 10^{7}$ spores/bee at 18 days post-inoculation ${ }^{31}$. However, diet had a considerable effect on the spore load observed in honey bees ${ }^{31}$. This difference illustrates the specific interaction between microsporidium and its host insect in regard to spore density for the development of microsporidiosis.

The morphological similarity between microsporidian species, particularly based on spore measurements in isolation, makes identification to species difficult. Therefore, other methods are needed to confirm identification. Classification based on spore morphology can be difficult and inconsistent because some microsporidia have complex life cycles and form various types of spores. In some cases, different sporulation cycles occur at different stages of the host. Some species can also form different types of spores in the same host and sometimes in the same tissues ${ }^{32}$. Such evidence indicates high diversity of the spore dimension; hence, molecular analysis is essential in the identification of microsporidian species $^{16}$.

The SSU rRNA sequence has been widely used as a molecular marker to estimate phylogenetic relationships between microsporidia, because it is a highly conserved gene ${ }^{12}$. However, this gene alone cannot be used to distinguish closely related species. This is a limitation of this gene for a more refined phylogenetic separations between species of this pathogen ${ }^{33,34}$. However, they can be used in the taxonomic classification at the genus level ${ }^{35,36}$. In this case, the species is well resolved, even amongst members of the same genus.

The use of microsporidia as a biological control agent offers many properties that make them attractive for pest control applications. They cause a chronic disease, which is debilitating to the host ${ }^{37}$. In addition, the transmission of microsporidia occurs by one or more several means - ingestion of spores present in the environment, parental transmission to offspring, which facilitates their multiplication in the target population ${ }^{38}$. This high transmissibility of microsporidia in host population coupled with low lethality is key for their high and long-term prevalence, which could be desirable for augmentative biocontrol strategy in forest pests. However, the method of transmission in G. platensis is currently unknown.

Associated pathogens may also be present in other countries, so there is a need for a more in-depth study aimed at detecting the microsporidium in Australia, native land to Gonipterus, and in other countries with the presence of ESB and other species of Gonipterus. We also need to investigate the host spectrum of this new microsporidiosis to native beetles in Brazil, especially concerning predatory beetles, in order to find out if this pathogen could be lethal or harmless to non-target hosts.

In summary, this data indicates a probable new species of this pathogen, providing support for new studies as well as for the elaboration of control methods to contribute to its integrated management in Brazilian eucalyptus plantations.

\section{Materials And Methods}


The research was conducted in the Laboratory of Biological Control of Forest Pests and Molecular Biology Laboratory in Department of Plant Protection, School of Agricultural Sciences, São Paulo State University (UNESP), Botucatu, SP, Brazil.

\subsection{Colony maintenance of Gonipterus platensis}

Adults of G. platensis, collected during field surveys in Eucalyptus plantations located in Botucatu, SP, Brazil, were housed in wooden cages $(40 \times 45 \times 80 \mathrm{~cm})$ with glass roofs and sides covered with voile fabric. These adults were fed on young leaves and buds of Eucalyptus urophylla (clone 433) (which were cleaned with hypochlorite solution ( $0.01 \%$ ) and neutral detergent prior to use), maintained in an airconditioned room at $25 \pm 1{ }^{\circ} \mathrm{C}, \mathrm{RH} 50 \pm 10 \%$ and photoperiod of $12: 12 \mathrm{~h}$ light:dark.

\subsection{Genomic DNA extraction}

For the extraction of genomic DNA, five insects with symptoms of infection (found dead with open wings and deformed abdomen) were washed in $0.85 \%(\mathrm{w} / \mathrm{v}) \mathrm{NaCl}$ sterile solution (Fig. 1). To extract genomic DNA from $G$. platensis, the abdomens of this five adults were macerated and added to a microtube with $160 \mu \mathrm{L}$ of $10 \%$ Chelex solution (Sigma-Aldrich) and $8 \mu \mathrm{L}$ of $20 \mathrm{mg} / \mathrm{mL}$ proteinase $\mathrm{K}$. The samples were placed in a thermal block at $95^{\circ} \mathrm{C}$ for 20 min, following a protocol for DNA extraction ${ }^{39}$, with Chelex $100 \AA$ resin (Sigma-Aldrich). The DNA was eluted and stored at $-20^{\circ} \mathrm{C}$ until use.

\subsection{Sequencing of SSU rRNA}

Polymerase chain reaction (PCR) was performed with Amplitaq Gold mastermix (Thermofisher Willington, MA) using the following parameters; $95^{\circ} \mathrm{C}, 10 \mathrm{~min}, 35$ cycles of $95^{\circ} \mathrm{C}, 30 \mathrm{~s} ; 58^{\circ} \mathrm{C}, 30 \mathrm{~s} ; 72{ }^{\circ} \mathrm{C}, 60 \mathrm{~s}$. PCR primers targeting the SSU rRNA were: 18f, 5'-CACCAGGTTGATTCTGCC-3' and 1537r, 5'-TTATGATCCTGC TAATGGTTC-3' 40 . The resultant amplicons were prepared using a Nextera XT library preparation kit and indices (Illumina inc, San Diego, CA). The samples were sequenced using an Illumina MiSeq system with a MiSeq V3 2 × 300 bp sequencing kit. The demultiplexed reads were quality trimmed to Q30 and assembled using CLC genomics workbench v20.0 (Qiagen inc., Valencia, CA). The consensus sequences for two full length SSU rRNA genes were accessioned in GenBank under MT367570-MT367571.

\subsection{Phylogenetic Analysis}

Phylogenetic analysis was conducted with MEGA X using Maximum Likelihood analysis and the Tamura 3-parameter model with a discrete gamma distribution (5 categories), as this model was found to be the best-fit using the maximum likelihood-based model selection algorithm implemented in MEGAX. The partial deletion (90\%) option was used, and the level of bootstrap support was calculated from 1000 replicates.

\subsection{Determination of microsporidian spore density in beetles}


Microsporidian spores were isolated from typically symptomatic insects, which were originated from the field, and maintained at the Laboratory for Biological Control of Forest Pests (LCBPF/UNESP, Botucatu, $\mathrm{SP}, \mathrm{Brazil})$. The infected insects were homogenized in nuclease-free water in 0.2-mL microtubes. The suspension was subjected to three series of centrifugation: 2,000 rpm for $10 \mathrm{~min}$ followed by 2 cycles at $12,000 \mathrm{rpm}$ for $1 \mathrm{~min}$. After each centrifugation, the supernatant was discarded. The spores accumulated at the bottom of the tube forming a "pellet", which was later resuspended in nuclease-free water (adapted from Solter et al., 2012). This procedure was performed individually for 10 insects, in order to determine the average concentration of spores per beetle $(n=10)$. The spores from each insect were purified and suspended in nuclease-free water and then immediately quantified with a Neubauer chamber at $400 \mathrm{X}$ magnification under a phase-contrast microscope (Leica DM 2500, Leica Microsystems, Heerbrugg, Switzerland). At the end of the counts, the microsporidium density per insect was determined.

\subsection{Phase contrast microscopy}

Spore immobilization and photomicrographs were performed according to the methods described in Vávra and Maddox (1976). Fresh spores were visualized from macerated body contents of infected insects after dilution in sterile $0.85 \% \mathrm{NaCl}$ solution $(\mathrm{w} / \mathrm{v})$. A drop of this macerate was transferred to a glass slide and the spores were examined under a phase-contrast microscope (Leica DM 2500, Leica Microsystems, Heerbrugg, Switzerland) at 400X magnification.

\subsection{Transmission electron microscopy}

The material was prepared at the Center for Electron Microscopy (Biosciences Institute - UNESP). Tissue samples from the digestive tract of $G$. platensis adults were fixed in Karnovsky's solution ${ }^{41}$ modified (glutaraldehyde $25 \%$ paraformoldehyde $8 \%$ and $0.2 \mathrm{M}$ monosodium / disodium phosphate buffer solution, $\mathrm{pH}$ 7.3). The samples were cut into small fragments of up to $2 \mathrm{~mm}^{3}$ for better fixation and incubated for at least $3 \mathrm{~h}$ at room temperature. The samples were removed from the fixative and washed 3 times for $5 \mathrm{~min}$ in $0.1 \mathrm{M}$ phosphate buffer with $\mathrm{pH} 7.3$, followed by immersing the material in osmium tetroxide for $2 \mathrm{~h}$. After, the material was washed 3 times for 10 min in distilled water and immersed in $0.5 \%$ uranyl acetate in distilled water for about $2 \mathrm{~h}$, in order to have the block contrast, revealing / highlighting the nucleic acids. Dehydration was accomplished with a series of solution containing an increasing amount of acetone. The series consisted of $10 \mathrm{~min}$ in $50 \%$ acetone, 2 washes for $10 \mathrm{~min}$ in $70 \%$ acetone, 3 washes for $15 \mathrm{~min}$ in 90\% acetone, and finally, 3 washes for $15 \mathrm{~min}$ in 100\% acetone.

The infiltration was done slowly using a 1:1 mixture of Araldite ${ }^{\circledR}$ resin $+100 \%$ acetone and left for approximately $12 \mathrm{~h}$ at room temperature. The fixed biological material was made in an appropriate form and further placed in an oven at $60^{\circ} \mathrm{C}$ for 2 to 3 days. Semi-thin cuts $(0.5 \mu \mathrm{m}$ thick) were made for choosing the region of interest and selected regions were trimmed again to further reduce the block surface allowing ultrathin cuts $(60-90 \mathrm{~nm})$ to be made and placed in appropriate grids. The cuts were contrasted with a saturated solution of uranyl acetate in $50 \%$ alcohol for about 20 min, followed by lead citrate for $10 \mathrm{~min}$. 
The slides were firstly examined under a light microscope (Zeiss Axioscop 2, Germany) to select the materials to be subsequently observed in the electron microscope. The analysis of the material was performed using the transmission electron microscope JEM 1011 (JEOL, Inc., Peabody, MA), operating at 40.60, 80 and 100KV JEO at the Electronic Microscopy Laboratory (ESALQ - USP, Piracicaba, SP, Brazil).

\subsection{Detection of microsporidiosis in different field-collected ESB populations from Southern Brazil}

In order to confirm the presence of the microsporidian pathogen in different field populations in from South to Southeast Brazil, insects from three different states were collected in commercial Eucalyptus plantations (Table 1). After collection in the field, the insects were brought to the laboratory, examined for microsporidiosis symptoms in adult beetles to calculate the percent natural infection, and then stored in a $-20^{\circ} \mathrm{C}$ freezer prior to dissection and microscopy to confirm the presence of the pathogen.

Table 1

Field sampling of Gonipterus spp. beetles retrieved from different localities in South and Southeast Brazil in 2019 for assessment of microsporidian pathogen incidence.

\begin{tabular}{|llll|}
\hline Sample & City and State & Eucalyptus host & Geographical coordinates \\
\hline 1 & São Jerônimo da Serra, PR & E. grandis $x$ E. urophylla & $-23.7516 \mathrm{~S} /-50.7955 \mathrm{~W}$ \\
\hline $2.1^{*}$ & Jaguarão, RS & E. dunnii & $-32.3760 \mathrm{~S} /-53.3263 \mathrm{~W}$ \\
\hline 2.2 & Jaguarão, RS & E. dunnii & $-32.3760 \mathrm{~S} /-53.3263 \mathrm{~W}$ \\
\hline 3 & Itaberá, SP & E. grandis $x$ E. urophylla & $-24.1403 \mathrm{~S} /-49.1091 \mathrm{~W}$ \\
\hline 5 & Brotas, SP & E. grandis $x$ E. urophylla & $-22.2117 \mathrm{~S} /-47.9985 \mathrm{~W}$ \\
\hline 6 & Lençóis Paulista, SP & E. grandis $x$ E. urophylla & $-22.8249 \mathrm{~S} /-48.8533 \mathrm{~W}$ \\
\hline 7 & Itararé, SP & E. grandis $x$ E. urophylla & $-24.1958 \mathrm{~S} /-49.2242 \mathrm{~W}$ \\
\hline 8 & Itararé, SP & E. grandis & $-24.1768 \mathrm{~S} /-49.1959 \mathrm{~W}$ \\
\hline 9 & Itararé, SP & E. grandis $x$ E. urophylla & $-24.1175 \mathrm{~S} /-49.2479 \mathrm{~W}$ \\
\hline 10 & Bom Sucesso do Itararé, SP & E. grandis $x$ E. urophylla & $-24.1495 \mathrm{~S} /-49.0802 \mathrm{~W}$ \\
\hline 11 & Bom Sucesso do Itararé, SP & E. grandis & $-24.1484 S /-49.1054 \mathrm{~W}$ \\
\hline 12 & Bom Sucesso do Itararé, SP & E. grandis & $-24.1485 \mathrm{~S} /-49.0980 \mathrm{~W}$ \\
\hline 13 & Laboratory rearing (Botucatu, SP) & E. grandis $x$ E. urophylla & $-22.8456 \mathrm{~S} /-48.4348 \mathrm{~W}$ \\
\hline$* 2.1:$ Sample of Gonipterus pulverulentus, another species found during field surveys. \\
\hline
\end{tabular}

\section{Declarations}




\section{Acknowledgements}

The study was financially supported by the following Brazilian agencies "Coordination for the Improvement of Higher Education Personnel (CAPES)". The authors acknowledge PROTEF (Forest Protection Programme) / IPEF to funding field trips and lab resources. This work was supported in part by the U.S. Department of Agriculture, Agricultural Research Service. Any opinions, findings, conclusions, or recommendations expressed in this publication are those of the author(s) and do not necessarily reflect the view of the U.S. Department of Agriculture. The mention of firm names or trade products does not imply they are endorsed or recommended by the USDA over other firms or similar products not mentioned. USDA is an equal opportunity provider and employer.

\section{Author's Contributions}

The study was conceived and designed by CJ, VRC and CFW; data were collected by CJ, VRC and LRSO; data analyses was realized by CJ, VRC, GMM and CFW, figure, table and manuscript preparation was carried out by CJ, VRC, GMM, LRSO, CAD and CFW; and all authors participates in the writing and approved the final version of the manuscript.

\section{Conflict of interest}

The authors declare that they have no competing interests.

\section{References}

1. Simões, R. A., Reis, L. G., Bento, J. M., Solter, L. F., \& Delalibera Jr, I. Biological and behavioral parameters of the parasitoid Cotesia flavipes (Hymenoptera: Braconidae) are altered by the pathogen Nosema sp. (Microsporidia: Nosematidae). Control. 63, 164-171 (2012).

2. Frago, E., Dicke, M., \& Godfray, H. C. J. Insect symbionts as hidden players in insect-plant interactions. Trends Ecol. Evol.27, 705-711 (2012).

3. Himler, A. G., Adachi-Hagimori, T., Bergen, J. E., Kozuch, A., Kelly, S. E., Tabashnik, B. E., \& Hunter, M. S. Rapid spread of a bacterial symbiont in an invasive whitefly is driven by fitness benefits and female bias. Science332, 254-256 (2011).

4. Lu, M., Wingfield, M. J., Gillette, N., \& Sun, J. H. Do novel genotypes drive the success of an invasive bark beetle-fungus complex? Implications for potential reinvasion. Ecology. 92, 2013-2019 (2011).

5. Vilcinskas, A., Stoecker, K., Schmidtberg, H., Röhrich, C. R., \& Vogel, H. Invasive harlequin ladybird carries biological weapons against native competitors. 340, 862-863 (2013).

6. Zhao, L., Lu, M., Niu, H., Fang, G., Zhang, S., \& Sun, J. A native fungal symbiont facilitates the prevalence and development of an invasive pathogen-native vector symbiosis. 94, 2817-2826 (2013).

7. Solter, L. F., Becnel, J. J., \& Vávra, J. Research methods for entomopathogenic microsporidia and other protists. Manual of Techniques in Invertebrate Pathology, 329-371 (2012). 
8. Maddox, J. V. Protozoan diseases. Epizootiology of Insect Diseases1, 417-452 (1987).

9. Latchininsky, A. V., \& VanDyke, K. A. Grasshopper and locust control with poisoned baits: a renaissance of the old strategy? Outlooks on Pest Management17, 105-111 (2006).

10. Sweeney, A. W., \& Becnel, J. J. Potential of microsporidia for the biological control of mosquitoes. Today. 7, 217-220 (1991)

11. Capella-Gutierrez, S., Marcet-Houben, M., \& Gabaldon, T. Phylogenomics supports microsporidia as the earliest diverging clade of sequenced fungi. BMC Biology10, 47-52 (2012).

12. Tokarev, Y. S., Huang, W. F., Solter, L. F., Malysh, J. M., Becnel, J. J., \& Vossbrinck, C. R. A formal redefinition of the genera Nosema and Vairimorpha (Microsporidia: Nosematidae) and reassignment of species based on molecular phylogenetics. Invertebr. Pathol.169, 107279 (2020).

13. Tooke, F. G. C. The Eucalyptus Snout beetle, Gonipterus scutellatus A study of its ecology and control by biological means. Union of South Africa, Department of Agriculture, Entomology Memoirs. 3, 1184 (1955).

14. Mapondera, T. S., Burgess, T., Matsuki, M., \& Oberprieler, R. G. Identification and molecular phylogenetics of the cryptic species of the Gonipterus scutellatus complex (Coleoptera: Curculionidae: Gonipterini). J. Entomol.51, 175-188 (2012).

15. Valente, C., Gonçalves, C. I., Monteiro, F., Gaspar, J., Silva, M., Sottomayor, M., \& Branco, M. Economic outcome of classical biological control: a case study on the Eucalyptus snout beetle, Gonipterus platensis, and the parasitoid Anaphes nitens. Ecol Econ. 149, 40-47 (2018).

16. Ansari, M. J., Al-Ghamdi, A., Nuru, A., Khan, K. A., \& Alattal, Y. Geographical distribution and molecular detection of Nosema ceranae from indigenous honeybees of Saudi Arabia. Saudi J. Biol. Sci24, 983991 (2017).

17. Ovcharenko, M., Świątek, P., Ironside, J., \& Skalski, T. Orthosomella lipaen. (Microsporidia) a parasite of the weevil, Liophloeus lentus Germar, 1824 (Coleoptera: Curculionidae). J. Invertebr. Pathol. 112, 33-40 (2013).

18. Weiser, J. A new microsporidian from the bark beetle Pityokteines curvidensGermar (Coleoptera, Scolytidae) in Czechoslovakia. Invertebr. Pathol. 3, 324-9 (1961).

19. Malone, Louise A. A New Pathogen, Microsporidium itiiti sp. (Microsporida), from the Argentine Stem Weevil, Listronotus bonariensis (Coleoptera, Curculionidae). J. Protozool. 32, 535-541 (1985).

20. Purrini, K., \& Weiser, J. Ultrastructural study of the microsporidian Chytridiopsis typographi (Chytridiopsida: Microspora) infecting the bark beetle, Ipstypographus (Scolytidae: Coleoptera), with new data on spore dimorphism. Invertebr. Pathol. 45, 66-74 (1985).

21. Yaman, M., Radek, R., Aslan, I., \& Erturk, O. Characteristic features of Nosema phyllotretae Weiser 1961, a microsporidian parasite of Phyllotreta atra (Coleoptera: Chrysomelidae) in Turkey. Studies Taipei. 44, 368 (2005).

22. Zhu, F., Shen, Z., Guo, X., Xu, X., Tao, H., Tang, X., \& Xu, L. A new isolate of Nosema sp. (Microsporidia, Nosematidae) from Phyllobrotica armata Baly (Coleoptera, Chrysomelidae) from China. Jour J. Invertebr. Pathol. 106, 339-342 (2011). 
23. Andreadis, T. G., Takaoka, H., Otsuka, Y., \& Vossbrinck, C. R. Morphological and molecular characterization of a microsporidian parasite, Takaokaspora nipponicus gen., n. sp. from the invasive rock pool mosquito, Ochlerotatus japonicus japonicus. J. Invertebr. Pathol. 114, 161-172 (2013).

24. Sapir, A., Dillman, A. R., Connon, S. A., Grupe, B. M., Ingels, J., Mundo-Ocampo, M., \& Sternberg, P. W. Microsporidia-nematode associations in methane seeps reveal basal fungal parasitism in the deep sea. Microbiol. 5, 43-52 (2014).

25. Solter, L. F., Maddox, J. V., \& McManus, M. L. Host specificity of microsporidia (Protista: Microspora) from European populations of Lymantria dispar (Lepidoptera: Lymantriidae) to indigenous North American Lepidoptera. Invertebr. Pathol. 69, 135-150 (1997).

26. Knell, J. D., Allen, G. E., \& Hazard, E. I. Light and electron microscope study of Thelohania solenopsae sp. (Microsporida: Protozoa) in the red imported fire ant, Solenopsis invicta. J. Invertebr. Pathol. 29, 192-200 (1977).

27. Henry, J. E., \& Oma, E. A. Pest control by Nosema locustae, a pathogen of grasshoppers and crickets. Microbial control of pests and plant diseases 1970-1980 (1981).

28. Vávra, J., \& Maddox, J. V. Methods in microsporidiology. In: Biology of the Microsporidia 281-319. Springer, Boston, MA (1976).

29. Simões, R. A., Feliciano, J. R., Solter, L. F., \& Delalibera Jr, I. Impacts of Nosema sp. (Microsporidia: Nosematidae) on the sugarcane borer, Diatraea saccharalis (Lepidoptera: Crambidae). Invertebr. Pathol.129, 7-12 (2015).

30. Inglis, G. D., Lawrence, A. M., \& Davis, F. M. Impact of a novel species of Nosema on the southwestern corn borer (Lepidoptera: Crambidae). Econ. Entomol.96, 12-20 (2003).

31. Zheng, H. Q., Lin, Z. G., Huang, S. K., Sohr, A., Wu, L., \& Chen, Y. P. Spore loads may not be used alone as a direct indicator of the severity of Nosema ceranae infection in honey bees Apis mellifera (Hymenoptera: Apidae). Econ. Entomol. 107, 2037-2044 (2014).

32. Goettel, M. S., Inglis, G. D., Lacey, L. A. Manual of techniques in invertebrate pathology. Academic Press, (2012).

33. Canning, E. U., Curry, A., Cheney, S., Lafranchi-Tristem, N. J., \& Haque, M. A. Vairimorpha imperfecta sp., a microsporidian exhibiting an abortive octosporous sporogony in Plutella xylostella L. (Lepidoptera: Yponomeutidae). Parasitology. 119, 273-286 (1999).

34. Tsai, S. J., Lo, C. F., Soichi, Y., \& Wang, C. H. The characterization of microsporidian isolates (Nosematidae: Nosema) from five important lepidopteran pests in Taiwan. Invertebr. Pathol.83, 51-59 (2003).

35. Cai, S. F., Lu, X. M., Qiu, H. H., Li, M. Q., \& Feng, Z. Z. Phagocytic uptake of Nosema bombycis (Microsporidia) spores by insect cell lines. Integr. Agric. 11, 1321-1326 (2012).

36. Dong, S., Shen, Z., Xu, L., \& Zhu, F. Sequence and phylogenetic analysis of SSU rRNA gene of five microsporidia. Current Microbiol. 60, 30 (2010). 
37. Becnel, J. J., \& Andreadis, T. G. Microsporidia in insects. The microsporidia and microsporidiosis 447501 (1999).

38. Knell, R. J., \& Webberley, K. M. Sexually transmitted diseases of insects: distribution, evolution, ecology and host behaviour. Rev. 79, 557-581 (2004).

39. Coombs, N. J., Gough, A. C., \& Primrose, J. N. Optimisation of DNA and RNA extraction from archival formalin-fixed tissue. Nucleic Acids Res. 27, e12-I (1999).

40. Huang, W. F., Tsai, S. J., Lo, C. F., Soichi, Y., \& Wang, C. H. The novel organization and complete sequence of the ribosomal RNA gene of Nosema bombycis. Fungal Genet. Bio/41, 473-481 (2004).

41. Karnovsky, M. J. A formaldehyde glutaraldehyde fixative of high osmolality for use in electron microscopy. J. Cell. Biol.27, 1A-149A (1965).

\section{Figures}

A

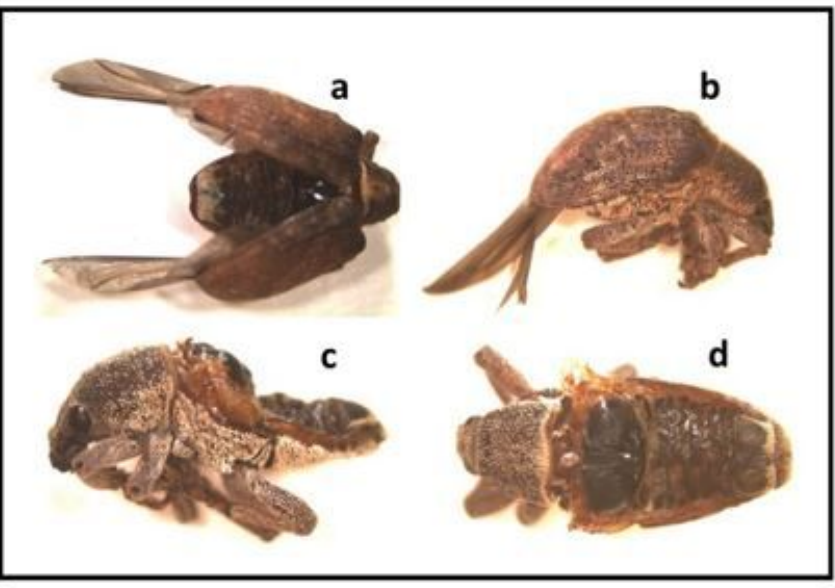

C

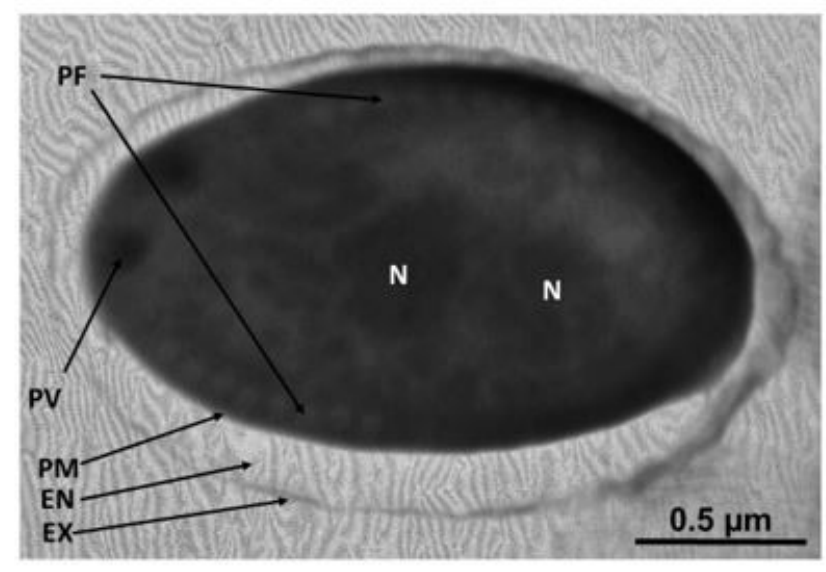

B

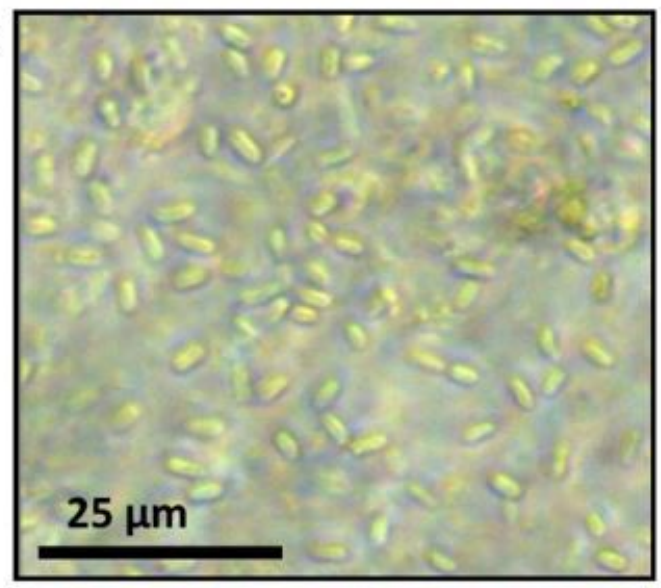

D

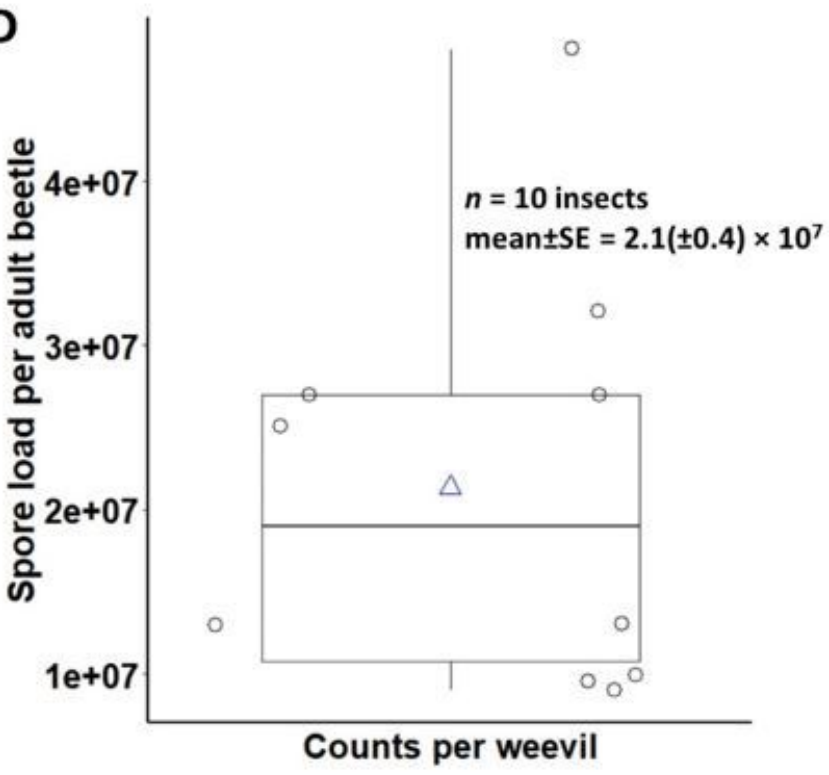

Figure 1 
Disease diagnosis for the new microsporidiosis in symptomatic adult beetles and spore load in infected beetles. A) Field-collected Gonipterus platensis adult beetles depicting visible symptoms of microsporidiosis disease. a - spread pair of wings exposing the abnormal and shrivelled abdomen; $b$ Side view of a dead insect showing the membranous pair of wings extended from the elytra; $c$ - Wingless adult with abnormal abdomen. $\mathrm{d}$ : Dorsal view of the abnormal abdomen. B) Microsporidian spores found in the hemolymph of G. platensis adults, observed under a phase contrast microscope. Scale bar $=25$ $\mu \mathrm{m}$. C) Electron micrograph of a longitudinal section of a mature microsporidian spore. The nucleus (binucleate, N), exospore (Ex), endospore (En), plasma membrane (PM), polar filament (PF) coiling posterolaterally around central diplokaryon showing 8 coils, and posterior vacuole (PV) are visible. Scale bar $=1 \mu \mathrm{m}$. D) Density of spores per insect determined by enumerating the spore load from smeared symptomatic beetles and performing counts under a phase contrast microscope using a Neubauer chamber at $400 \mathrm{X}$ magnification. 


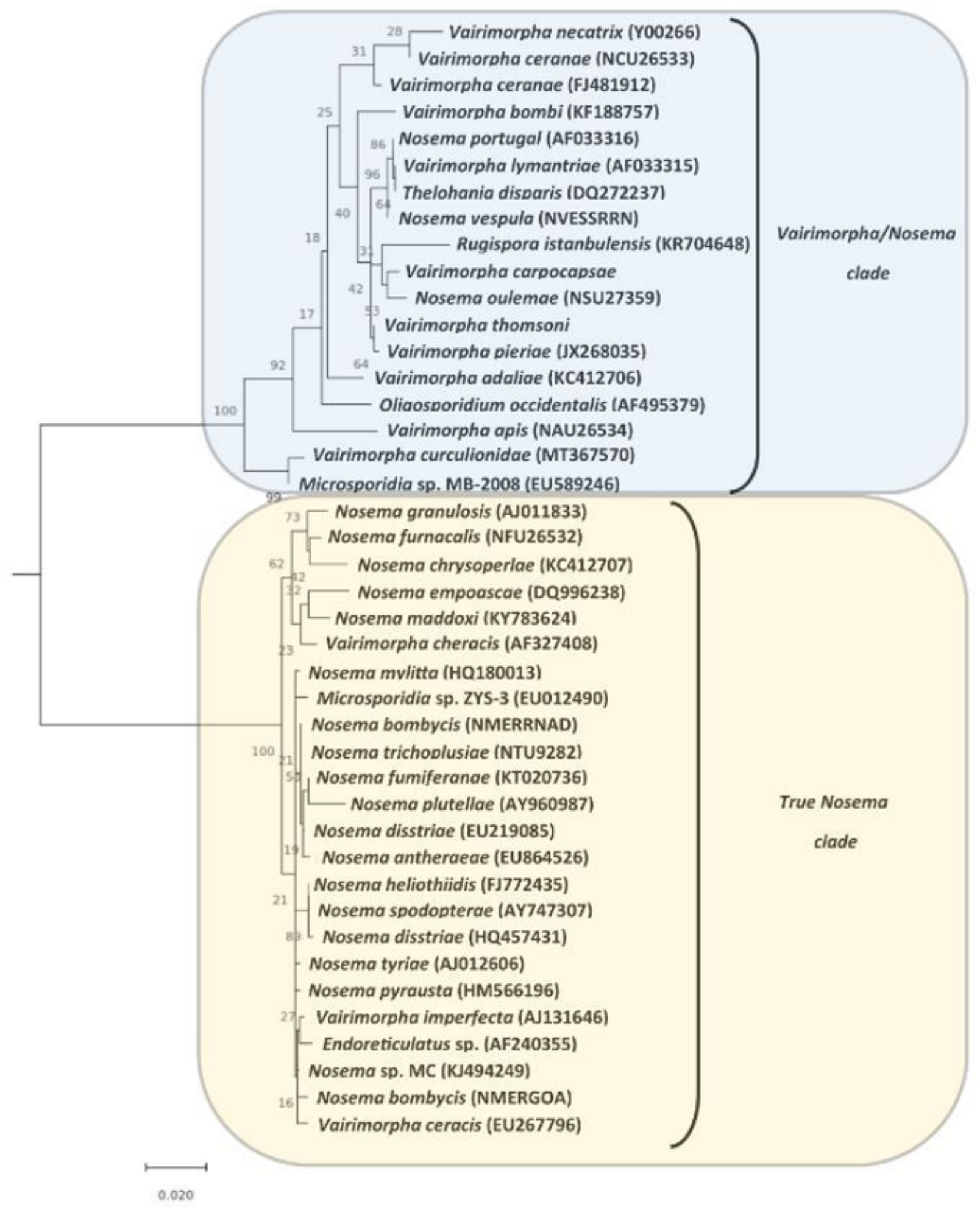

Figure 2

Phylogenetic tree based upon a small subunit rRNA gene alignment of 1068 positions in MEGA X with the Maximum Likelihood method using the Tamura 3-parameter model with a gamma distribution model. Values at branches indicate bootstrap support. The new microsporidium isolate is assigned to the Vairimorpha genus with a proposed name of Vairimorpha curculionidae. The outgroup was Ordospora colligata and is not shown. 


\section{A}

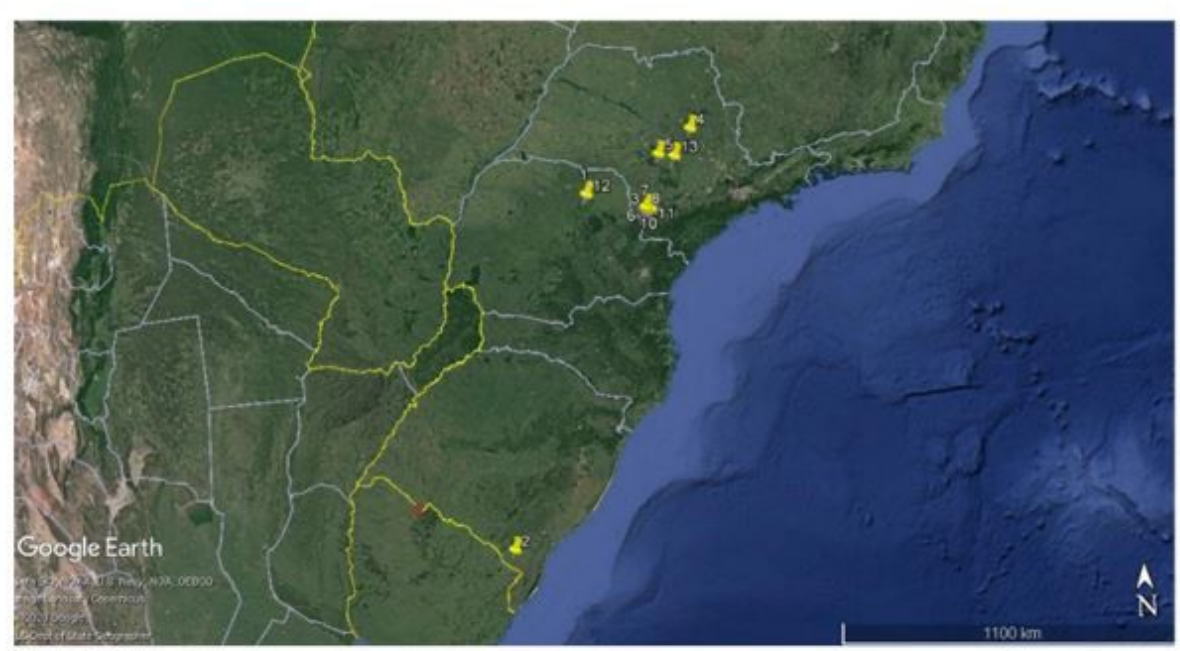

B SãoJerônimodaSerra_PR_2 SãoJerônimodaSerra_PR_1 LençóisPaulista_SP Jaguarão_RS_2 Jaguarão_RS_1
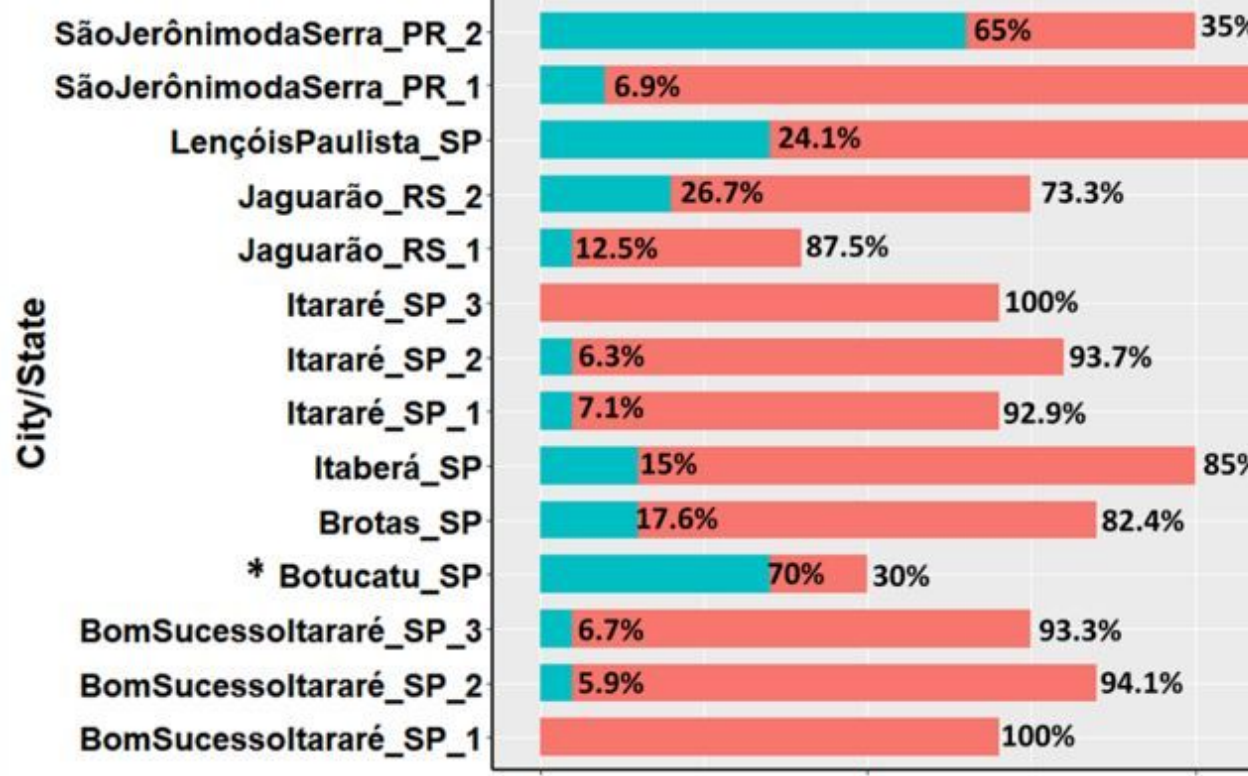

$93.1 \%$

\begin{tabular}{|c|c|}
\hline $6.9 \%$ \\
\hline $24.1 \%$ \\
\hline
\end{tabular}

$73.3 \%$

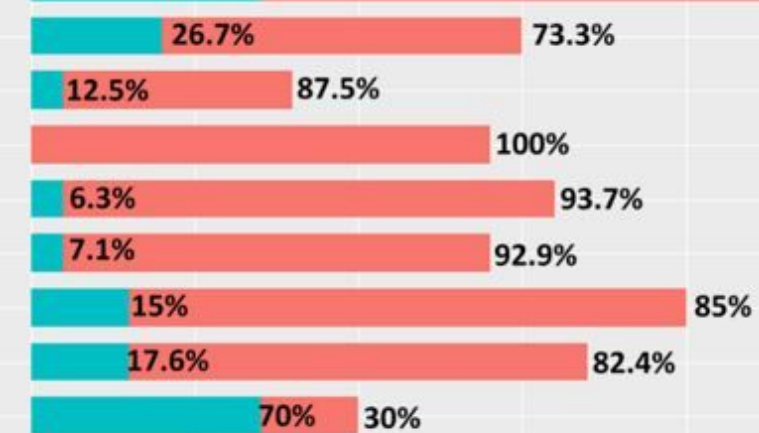

\section{$6.7 \%$} $93.3 \%$

\section{$5.9 \%$} $94.1 \%$ 0

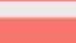
$100 \%$ $\begin{array}{cc}10 & 20 \\ \text { Number of field-collected beetles } & 30\end{array}$

status

Healthy Infected

\section{Figure 3}

Natural prevalence of the new microsporidian pathogen in different field populations of the Eucalyptus snout beetle. A) Collection field sites (marked with yellow pins) mapped with Google Earth ${ }^{\circledR}$ showing where Gonipterus platensis adults were sampled in South and Southeast Brazil from commercial Eucalyptus plantations. B) Proportion of infected beetles (number of infected versus number of healthy adults) by location. Survey of 14 distinct geographical points were performed to collect adult beetles for diagnosis based on typical microsporidiosis symptoms and presence of microsporidian spores in the hemolymph: one collection point was made in Botucatu, SP ( ${ }^{\star}$ from insect colony kept in the lab); three samples from Bom Sucesso do Itararé, SP; three from Itararé, SP; one from Lençóis Paulista, SP; one from Brotas, SP; one from Itaberá, SP; two from Jaguarão, RS (Gonipterus pulverulentus was collected only in sample 2); and two from São Jerônimo da Serra, PR. Note: The designations employed and the presentation of the material on this map do not imply the expression of any opinion whatsoever on the 
part of Research Square concerning the legal status of any country, territory, city or area or of its authorities, or concerning the delimitation of its frontiers or boundaries. This map has been provided by the authors. 